\title{
Effects of Sulfonylureas on Histochemical and Ultracytochemical Calcium Distribution in B-Cells of Mice*
}

\author{
G. Klöppel and H.-J. Schäfer \\ Institute of Pathology, University of Hamburg, Federal Republic of Germany
}

\begin{abstract}
Summary. The study examines the effects of sulfonylurea compounds on the histo- and ultracytochemical calcium distribution within the B-cells of mice using the glyoxal-bis-(2-hydroxyanil) (GBHA) and the pyroantimonate method combined with X-ray microanalysis. Treatment with tolbutamide $(200 \mathrm{mg} / \mathrm{kg})$, glibenclamide $(2 \mathrm{mg} / \mathrm{kg})$ and glisoxepide $(2 \mathrm{mg} / \mathrm{kg})$, causing moderate hypoglycemia and B-cell degranulation, was associated with an unchanged (30,90 min) or slightly increased (180, $360 \mathrm{~min}, 4,42 \mathrm{~d})$ GBHA staining intensity of the islet cells compared with controls. Ultracytochemically sulfonylureas provoked, compared with controls, a redistribution of calcium-rich, electron dense pyroantimonate precipitates (EDPP). Precipitation predominantly occurred along the inner surface of the plasma membranes and within the granule halos. In contrast, the cytoplasmic matrix, the Golgi complexes and the rough endoplasmic reticulum contained only few fine precipitates. - The sulfonylureas investigated exerted identical effects on the histo- and ultracytochemical calcium distribution in B-cells. - The results indicate that sulfonylurea-induced insulin secretion is associated with an accumulation and redistribution of calcium within the B-cells. This supports the hypothesis that an altered calcium handling by the B-cell mainly accounts for the insulinotropic effect of sulfonylureas.
\end{abstract}

Key words: Sulfonylureas, insulin secretion, B-cells, calcium demonstration, calcium localization, histochemistry, ultracytochemistry.

\footnotetext{
* Supported by Deutsche Forschungsgemeinschaft, SFB 34, Endocrinology, Hamburg.

Part of this work was presented in preliminary form at the $10^{\text {th }}$ Congress of the German Diabetes Association, Ulm 1975.
}

The sulfonylurea-induced insulin secretion is a well known phenomenon of therapeutic importance. The intimate mode of action of sulfonylurea compounds in the pancreatic B-cells is, however, poorly understood. According to Hellman et al. [16] sulfonylureas bind reversibly to $B$-cell membranes, from where they may exert their insulinotropic effect. Matthews and Dean [32] found alterations of membrane potentials in islet cells after sulfonylurea stimulation, indicating altered ionic fluxes. Malaisse et al. [30] assume that the insulinotropic effect of sulfonylureas is mediated by cytosol accumulation of calcium in the B-cells, since they found an increased net uptake of ${ }^{45} \mathrm{Ca}$ in the pancreatic islets after sulfonylurea stimulation.

Calcium, which is thought to play an essential role in insulin secretion $[4,11,12,13,14,15,27,28,33$, $43]$, was demonstrated both histochemically [21, 37] and ultracytochemically $[17,21,38]$ within the B-cells of mouse islets using the glyoxal-bis-(2-hydroxyanil) (GBHA) method [18] and the pyroantimonate technique [22], combined with $\mathrm{X}$-ray microanalysis for controlling specificity. Hypo- and hyperglycaemia were found to cause characteristic changes in the intensity of the calcium-specific GBHA staining of the islets and the ultrastructural distribution pattern of calcium rich precipitates within the B-cells, indicating that inhibition or excitation of insulin secretion is associated with an altered calcium handling by the B-cell $[37,38]$. On the basis of these findings the present report examines the effects of sulfonylureas on the histochemical and ultracytochemical distribution of calcium within B-cells of mice.

\section{Material and Methods}

44 fasting male white mice, weighing 25 to $35 \mathrm{~g}$, were injected subcutaneously with tolbutamide (Rastinon; Hoechst A.G. Frankfurt), glibenclamide (HB 419; 
Table 1. Grouping and treatment. Number of animals in parenthesis

\begin{tabular}{lllllllll}
\hline Agent & Treatment & $\min$ & $\min$ & $\min$ & $\min$ & Treatment & days & days \\
\hline Tolbutamide & $1 \times 200 \mathrm{mg} / \mathrm{kg}$ & $30_{(3)}$ & $90_{(4)}$ & $180_{(4)}$ & $360_{(4)}$ & $2 \times 200 \mathrm{mg} / \mathrm{kg}$ daily & $4(5)$ & - \\
Glibenclamide & $1 \times 2 \mathrm{mg} / \mathrm{kg}$ & $30_{(3)}$ & $90_{(4)}$ & $180_{(4)}$ & $360_{(4)}$ & $2 \times 2 \mathrm{mg} / \mathrm{kg}$ daily & $4(5)$ & $42_{(8)}$ \\
Glisoxepide & $1 \times 2 \mathrm{mg} / \mathrm{kg}$ & $30_{(2)}$ & $90_{(4)}$ & $180_{(4)}$ & $360_{(4)}$ & $2 \times 2 \mathrm{mg} / \mathrm{kg} \mathrm{daily}$ & $4(5)$ & $42_{(10)}$ \\
$0.9 \% \mathrm{NaCl}$ & $1 \times 0.5 \mathrm{ml}$ & $30_{(2)}$ & $90_{(2)}$ & $180_{(2)}$ & $360_{(2)}$ & $2 \times 0.5 \mathrm{ml} \mathrm{daily}$ & $4(2)$ & $42_{(5)}$ \\
\hline
\end{tabular}

Hoechst A.G. Frankfurt) and glisoxepide (Prodiaban; Bayer A.G. Leverkusen) and killed after various time intervals (Table 1). 8 fasting mice receiving $0,9 \%$ $\mathrm{NaCl}$ served as controls. Another 33 animals receiving a normal standard diet were repeatedly injected with the same agents at the same dosages for prolonged periods (Table 1). They were killed 90 min after the last injection. 7 animals served as controls.

Before treatment and at sacrifice blood samples were collected from the retro-orbital venous plexus for determination of glucose by the glucose oxidase method (Boehringer Co., Mannheim). The mice were then killed while under deep ether narcosis. Small pieces of pancreas were taken for electron microscopy and ultracytochemical cation detection. The remainder of the gland was taken for histochemical calcium detection and conventional histology.

For the latter, Bouin fixed paraffin embedded pancreatic tissue was stained with Gomori's aldehyde fuchsin (AF) or periodic acid Schiff (PAS). The AF staining intensity was arbitrarily evaluated in at least 4 to 6 islets in two sections of each pancreas and graded from 0 to 4 ( 0 - no intensity; 1 -poor; 2 -moderate; 3 -marked; 4 - strong). - For histochemical calcium demonstration small pieces of pancreatic tissue were immersed in a staining fixative consisting of $3.4 \%$ $\mathrm{NaOH}$ in $75 \%$ ethanol containing $0.1 \mathrm{~g} / \mathrm{ml}$ glyoxalbis-(2-hydroxyanil) (GBHA; Serva Heidelberg) for 12 to $18 \mathrm{~h} \mathrm{[18].} \mathrm{After} \mathrm{rinsing} \mathrm{in} \mathrm{absolute} \mathrm{ethanol} \mathrm{and}$ xylene the specimens were embedded in paraffin. Sections were dry-mounted on albuminized slides by means of careful finger pressure. The GBHA islet staining intensity was arbitrarily evaluated in at least 4 to 6 islets in several sections of each pancreas and graded as indicated for AF staining. - For conventional electron microscopy pancreatic tissue fragments were fixed and processed as described previously [20]. - For ultracytochemical cation demonstration a modification of two pyroantimonate techniques were used $[10,22]$. Small pancreatic specimens were fixed in an ice cold solution containing 3\% glutaraldehyde and $2 \%$ potassium pyroantimonate adjusted to $\mathrm{pH} 7.3$ by $0.01 \mathrm{~N}$ acetic acid for $2 \mathrm{~h}$. The tissue was then rinsed in a solution of $2 \%$ potassium pyroantimonate and $5 \%$ sucrose $(\mathrm{pH} \mathrm{7.3)}$, postfixed for $1 \mathrm{~h}$ in a solution of $1 \% \mathrm{OsO}_{4}$ and $2 \%$ potassium pyroantimo- nate $(\mathrm{pH} 7.3)$ and washed three times in $7 \%$ sucrose. The fixed tissue was dehydrated in graded ethanol and, after passing propyleneoxide, embedded in Epon 812. Ultrathin sections were cut on a Reichert ultramicrotome OM U2, picked up on copper grids and viewed either unstained or stained with uranylacetate and lead citrate in a Zeiss electron microscope EM 10. - Morphometric studies on the distribution of EDPP in B-cells were done in 8 animals, in order to substantiate the qualitative findings. The animals belonged to the glibenclamide treated group ( $30 \mathrm{~min}[\mathrm{n}=2], 180$ $\min [n=2], 42$ days $[n=2])$ and the controls $(n=2)$. Two sections were taken at $10 \mu$ intervals from two randomly sampled pancreatic tissue blocks of each animal. Electron micrographs were taken from B-cells in the islet centre, in the paracentral islet region and at the islet periphery, and were printed with a final magnification of 16700 . A point counting system (total number of points 255 ; grid constant $0.6 \mu$ ) was used to measure the percentage of cell organelles or structures associated with EDPP. Only those compact or granular EDPP were counted having a diameter above 30 $\mathrm{m} \mu$ and deposited within granule halos, mitochondria, the cytoplasm including the rough endoplasmic reticulum and the Golgi complexes, and at the inner surface of the cell membranes. The number of EDPP associated with granules, mitochondria, cytoplasm and cell membranes was expressed as percentage of the total number of EDPP counted in the B-cells of one experimental group. - X-ray microanalysis was done on pyroantimonate stained sections. The sections were mounted on nickel grids. The analytical system consisted of an electron microscope JEOL JEM $100 \mathrm{C}$ with a high resolution scanning devise combined with an energy-dispersive microanalytical system (Link Ltd.). Analytical spectra were obtained from precipitates at various cell sites.

\section{Results}

\section{Blood Glucose Examinations}

All mice receiving sulfonylureas showed lowered blood glucose values compared with controls (105 $\mathrm{mg} / 100 \mathrm{ml} \pm 10 \mathrm{SD})$. The lowest blood glucose values 


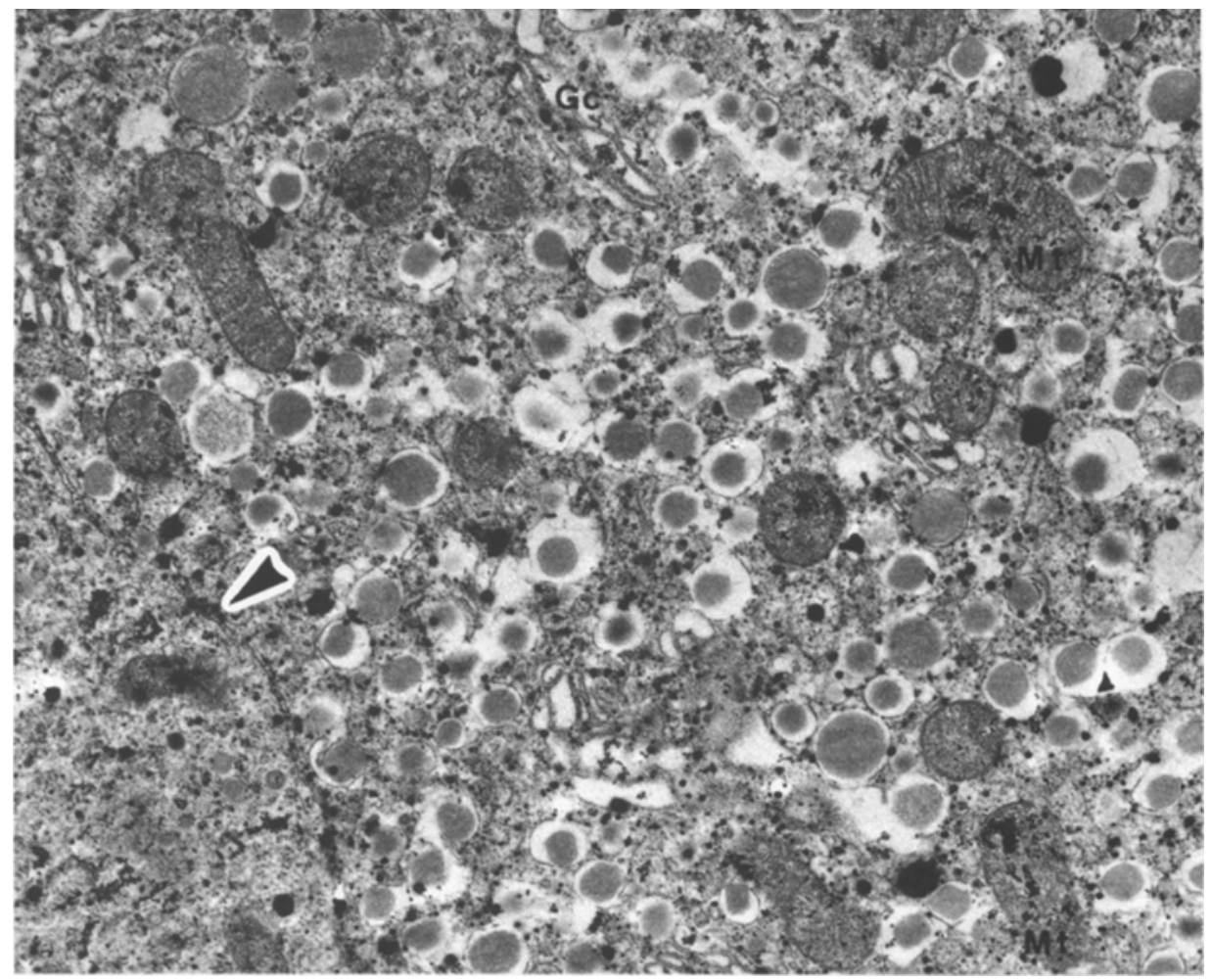

Fig. 1. B-cell of normoglycaemic mouse: many electron dense precipitates (EDPP) within the cytoplasmic matrix, the Golgi complexes (Gc) and the mitochondria (Mt). Only few precipitates within the granule halos and along the plasma membranes (arrow). K-pyroantimonate reaction. Uranylacetate and lead citrate staining. $\times 16700$

were found $360 \mathrm{~min}$ after injection $(58 \mathrm{mg} / 100 \mathrm{ml} \pm$ $12 \mathrm{SD})$. There were no significant differences in these values between tolbutamide, glibenclamide and glisoxepide at the dosages tested.

\section{Histology}

The pancreatic islets of the controls showed well granulated B-cells as estimated by Gomori's AF staining. The intensity of the AF staining of the B-cells was graded as 3 (marked). In contrast, the B-cells of sulfonylurea treated animals showed moderate loss of AF-intensity, indicating degranulation. The AF-intensity was most reduced after 360 min (grade 1-2). However, even at this time B-cell degranulation was not complete and affected the B-cells inequally. Repeated administration of sulfonylureas in the long term experiments did not result in a further decrease in B-cell granularity. Apart from degranulation no further B-cell alterations occurred.

\section{Histochemical Calcium Demonstration}

In controls the GBHA method for calcium detection revealed an intense red staining of the islets, which was graded as 3 (marked). In the sulfonylurea treated mice, which developed hypoglycaemia and degranulation, the intensity of GBHA islet staining slightly increased in time to grade 4 (strong) or remained, at least, unchanged (grade 3). After $360 \mathrm{~min}$, when the B-cells showed a grade 1-2 AF staining intensity and hypoglycaemia was most pronounced, GBHA staining still remained marked (grade 3 ) or strong (grade 4 ). In the chronically sulfonylurea treated mice the GBHA staining intensity of the islets was grade 3 or grade 4 , respectively.

\section{Ultrastructure}

The ultrastructure of pancreatic B-cells in sulfonylurea treated small rodents has been described in detail previously $[19,24,25,34,42]$. Thus, these findings can be briefly summarized. As signs of enhanced secretory activity the B-cells in acutely sulfonylurea treated mice appeared moderately degranulated, showing activated Golgi complexes which were surrounded by an increased number of microvesicles. As peculiar ultrastructural phenomena of unknown significance an enlargement of many halos around the granule core, the presence of small bar- 


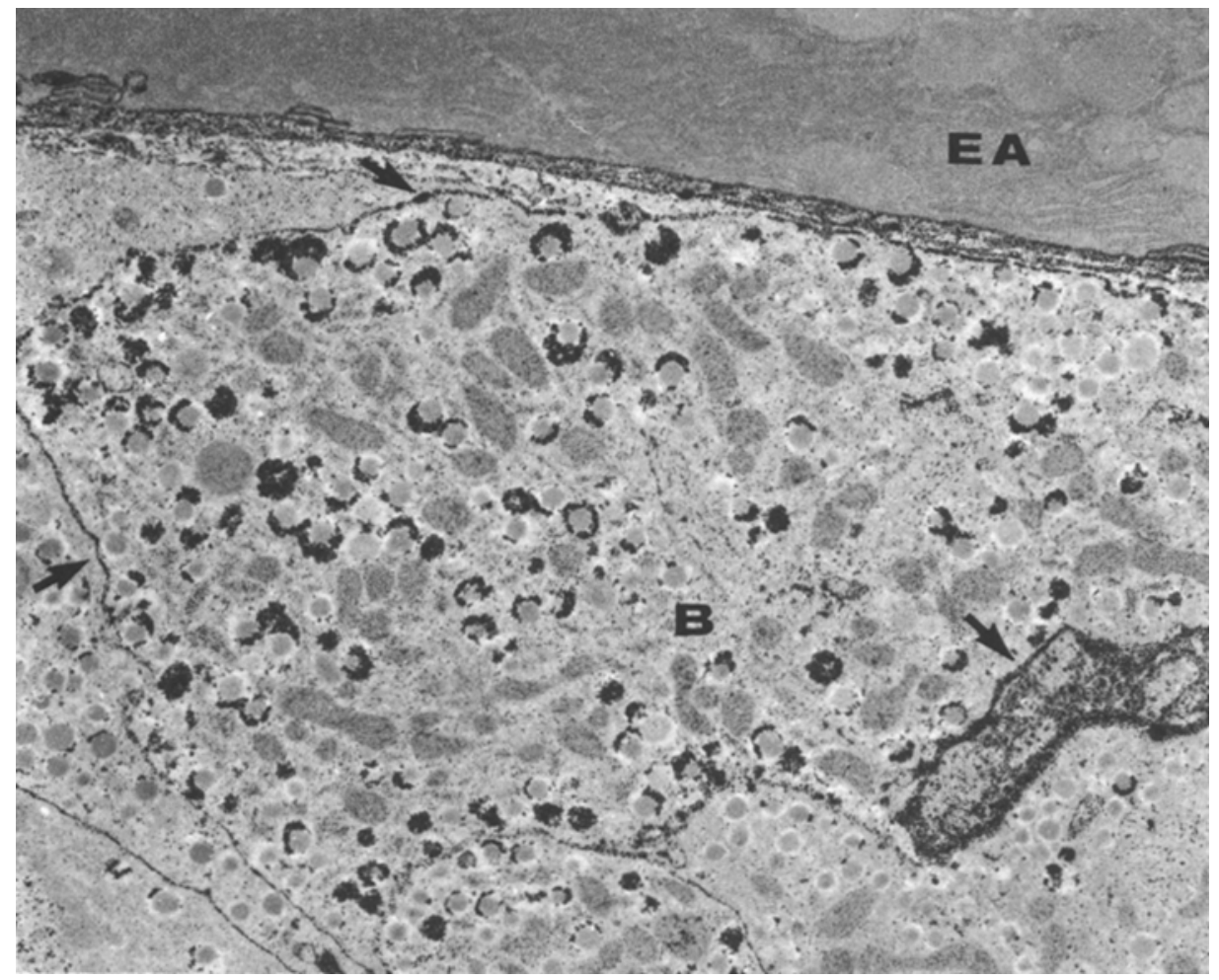

Fig. 2. B-cell (B) of hypoglycaemic mouse repeatedly injected with sulfonylureas over a period of 3 days: distribution pattern of calcium-rich EDPP of the "active type" characterized by a marked deposition of precipiates within the granule halos and along the cell membranes (arrows). At top, part of an exocrine acinar cell (EA) almost lacking precipitates at this magnification. K-pyroantimonate reaction. Unstained. $\times 9800$

like electron opaque deposits within single halos and the occurrence of multigranular bodies were observed. - In chronically treated mice the fine structure of the B-cells was comparable with that described in acutely treated mice.

\section{Ultracytochemical Cation Precipitation}

In the normoglycaemic controls the pattern of the electron dense pyroantimonate precipitates (EDPP) was the same as described in detail previously [38] (Fig. 1). Numerous small EDPP were found scattered throughout the cytoplasmic matrix, only occasionally attached to the inner and outer surface of the $\beta$-granule membrane. Distinct precipitates also occurred in mitochondria, where as only few were deposited within the Golgi complexes, the endoplasmic reticulum and in the vicinity of the plasma membranes. Marked precipitation was found in the intercellular spaces between the B-cells. A- and D-cells exhibited similar but more sparse EDPP patterns than B-cells. In acinar cells of the exocrine pancreas precipitation was weak and never reached the intensity seen in the islet cells.
In contrast to the controls precipitation within the B-cells of sulfonylurea treated mice, though differing considerably in intensity from cell to cell, mainly occurred at two cell sites: the plasma membrane and the halos of the secretory granules (Fig. 2). At 30 min post injection EDPP deposits were already found to be increased along the inner surface of the plasma membrane (Fig. 3). Moreover, the halos around single granule cores contained compact EDPP. At $90 \mathrm{~min}$, $180 \mathrm{~min}$ and $360 \mathrm{~min}$ there were further increases in halo located EDPP, while the degree of EDPP deposition along the inner surface of the plasma membrane remained constant (Fig. 4). The halo-located EDPP, frequently showing a granular substructure, filled the whole space between granule core and membrane. The granule cores lacked precipitates. The deposition of fine EDPP associated with the cytoplasmic region occupied by the ribosomes and the endoplasmic reticulum decreased in time, which became most evident at $180 \mathrm{~min}$ and $360 \mathrm{~min}$. The degree of precipitation within the mitochondrial matrix, the Golgi complexes and the nucleus remained constant compared with the controls. An EDPP labelling of microtubular structures could not be observed with certainty. The non- 


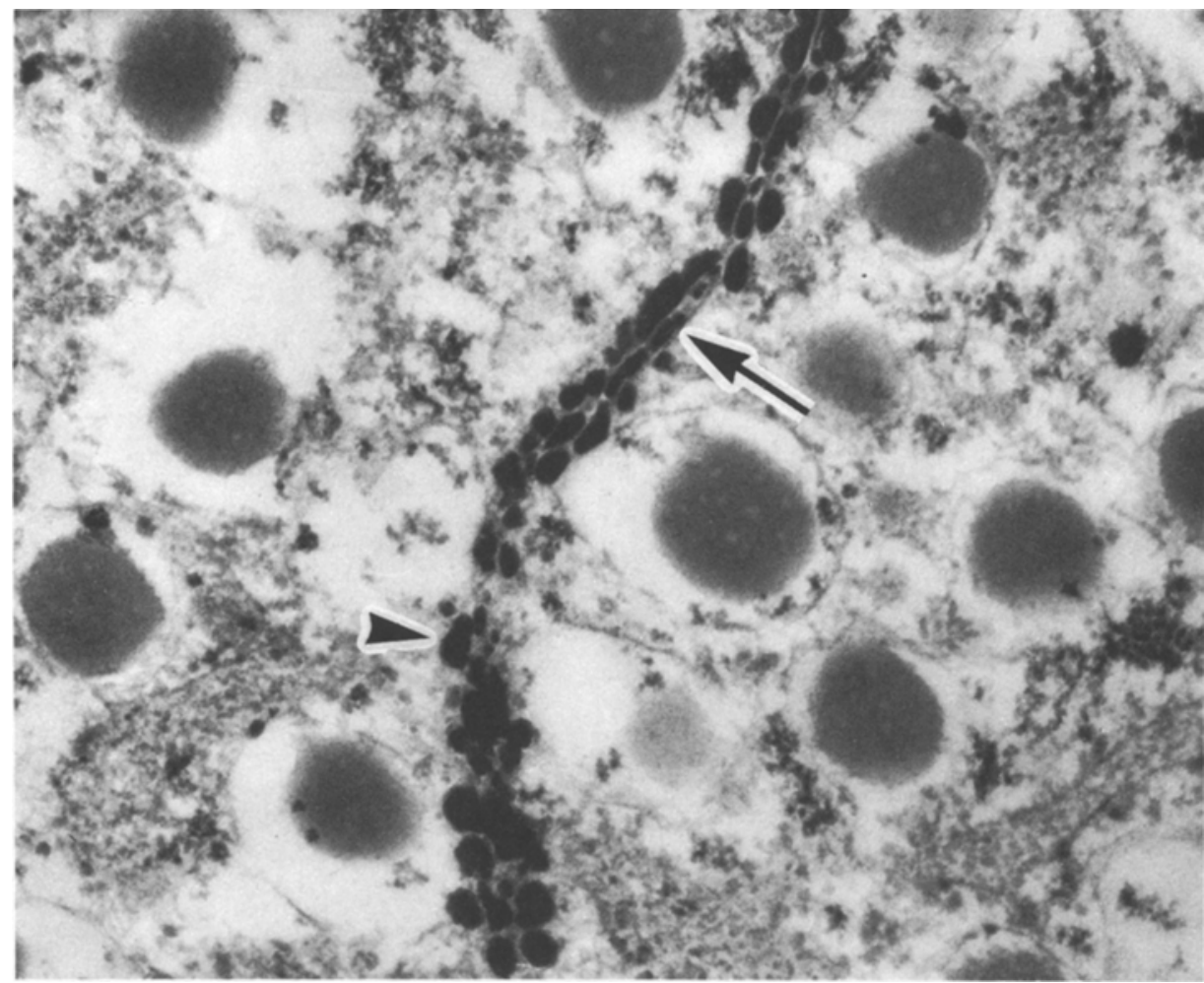

Fig. 3. Parts of two B-cells 30 min after sulfonylurea stimulation: heavy deposits of calcium-rich EDPP are aligned at the outer (long arrow) and, particularly, the inner surface (short arrow) of the plasma membranes. K-pyroantimonate reaction. Uranylacetate and lead citrate. $\times 56000$

B-cells exhibited an unaltered precipitation pattern in all experimental groups. In particular, no increased labelling of granule halos and plasma membranes occurred. Outside the islet cells abundant precipitates of irregular size filled the intercellular and perivascular spaces and were also present within the lumina of the sinusoids. - In chronically sulfonylurea treated mice the features of the EDPP pattern of the islet cells were identical with those described above.

\section{Morphometry}

Morphometry was only performed in glibenclamide treated animals, since tolbutamide and glisoxepide produced identical qualitative findings. Table 2 summarizes the morphometric data concerning the distribution of EDPP in B-cells of mice treated with glibenclamide. It clearly indicates that glibenclamideinduced stimulation of insulin release provoked a general redistribution of EDPP in the B-cells, resulting in an increased percentage of granule and cell membrane associated EDPP and a decreased percentage of cytoplasm associated EDPP. The ultrastructural preservation and the varying substructure and size of the EDPP allows no further quantitative evaluations.

\section{Elemental X-Ray Microanalysis}

It was previously shown by $\mathrm{X}$-ray microanalysis that the pancreatic islets intensively stained with GBHA contain high amounts of calcium. This confirmed the calcium specificity of the GBHA staining technique [37].

The X-ray spectra of pyroantimonate precipitates deposited at some typical cell sites within sulfonylurea-stimulated B-cells are shown in Figure 5. In these spectra the antimony peaks have peen subtracted by a computerized stripping program, which separates overlapping peaks. Details of this procedure will be reported elsewhere (Schäfer, in preparation). The nickel and osmium peaks originated from the supporting grid, respectively the fixation medium. The chlorine peaks probably arose from the embedding medium. The EDPP at the cell membranes and within the halos of the secretory granules revealed significant calcium peaks ( $K \alpha$ and $K \beta$ ), whereas these signals were absent from the pyroantimonate negative core of the secretory granules. Signals indicative of other cations as for example sodium, magnesium or zinc were lacking. This implies that the latter cations were either absent or only present in amounts too small to evoke a signal in the analytical system used. 


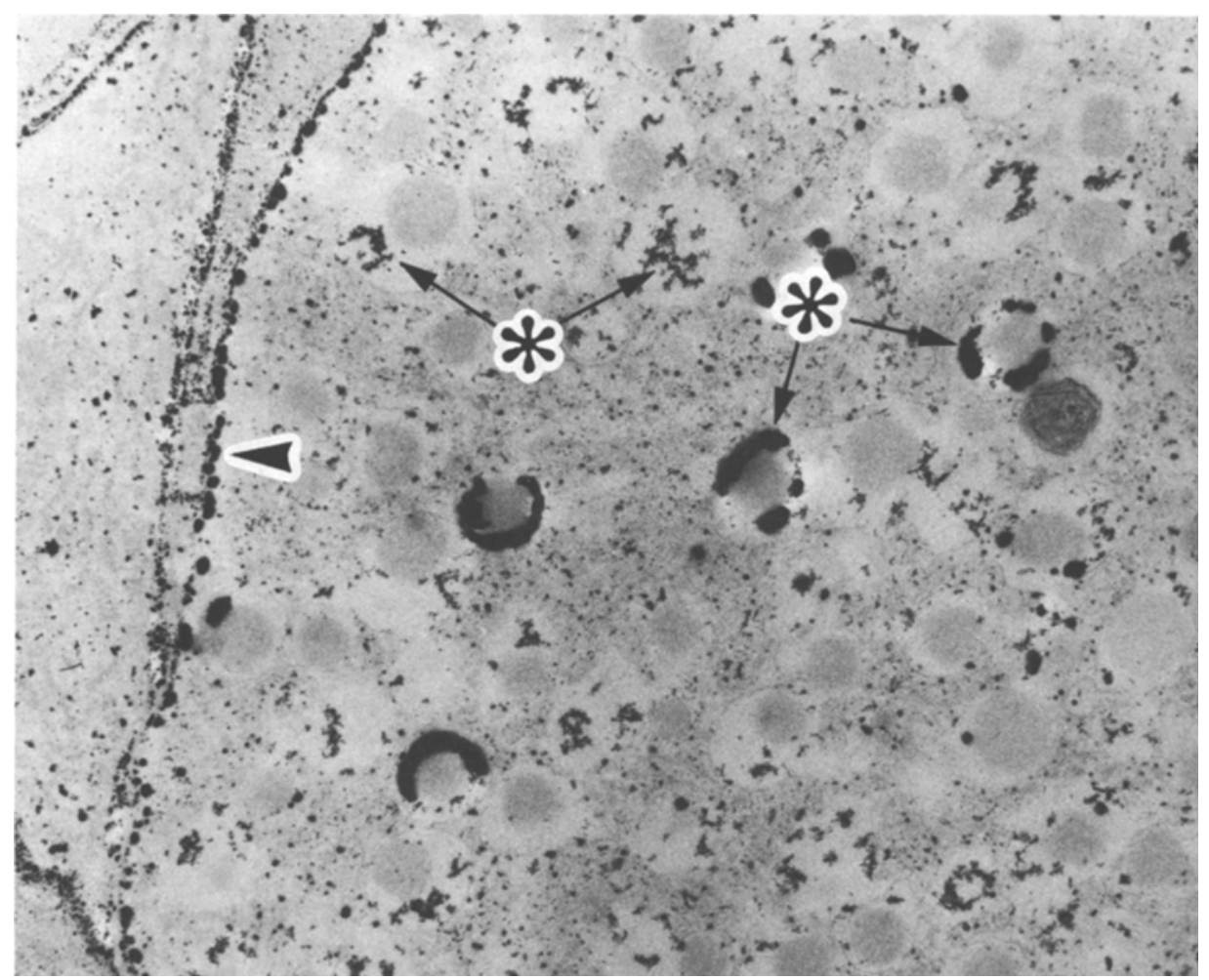

Fig. 4. Part of a B-cell $180 \mathrm{~min}$ after sulfonylurea stimulation. The majority of the calcium-rich EDPP are located within the granule halos exhibiting a granular or compact substructure (asterix). Dot-like precipitates are associated with the inner surface of the plasma membrane (short arrow). K-pyroantimonate. Unstained. $\times 25000$

Table 2. Morphometric data for distribution of calcium rich EDPP in B-cells of glibenclamide treated mice and controls. The number of cell organelles or structures associated with EDPP is expressed as percentage (mean value) of the total number of EDPP counted with a point counting system

\begin{tabular}{lllll}
\hline Treatment & $\begin{array}{l}\text { Mito- } \\
\text { chondria }\end{array}$ & $\begin{array}{l}\text { Granule } \\
\text { halos }\end{array}$ & $\begin{array}{l}\text { Cell membrane } \\
\text { inner surface }\end{array}$ & $\begin{array}{l}\text { Cytoplasmic } \\
\text { area }\end{array}$ \\
\hline $0.9 \% \mathrm{NaCl}$ & $23.4 \%$ & $10.3 \%$ & $4.3 \%$ & $62.0 \%$ \\
& $(18-31)$ & $(8-11)$ & $(2-9)$ & $(49-71)$ \\
Glibenclamide & & & & $37.0 \%$ \\
30 min & $10.6 \%$ & $20.0 \%$ & $(28-43)$ & $(28-35)$ \\
& $(8-15)$ & $(17-21)$ & $16.6 \%$ & $25.2 \%$ \\
180 min & $12.3 \%$ & $46.0 \%$ & $(13-20)$ & $(15-40)$ \\
& $(10-15)$ & $(30-50)$ & $23.0 \%$ & $23.5 \%$ \\
$42 \mathrm{~d}$ & $13.0 \%$ & $40.5 \%$ & $(16-38)$ & $(12-33)$ \\
\hline
\end{tabular}

\section{Discussion}

Previous studies have shown that calcium can be histochemically demonstrated in high amounts within the pancreatic islets of normoglycemic mice using the GBHA method $[21,37]$. The calcium specificity was confirmed by microanalysis [38]. Furthermore, by stimulating insulin secretion with antiinsulin serum (AIS) induced hyperglycaemia, it was found that the
GBHA staining intensity of the islets decreased, paralleling B-cell degranulation [37]. Using sulfonylureas for excitation of insulin secretion in mice the islets revealed, when compared with controls, a constant or even slightly increased staining intensity at $180 \mathrm{~min}$ and, particularly, at $360 \mathrm{~min}$ following stimulation, associated with a modest, but distinct, B-cell degranulation.

Ultracytochemically the pyroantimonate tech- 
Fig. 5. X-ray microanalytical spectra from EDPP located within a granule halo and attached to the cell membrane as well as from an EDPP-free granule core of a mouse B-cell activated with glibenclamide. After subtraction of the antimony peaks the spectographs from the halo and plasma membrane associated EDPP show a significant calcium peak, which is absent from the granule core. Note also the absence of significant peaks of other cations. Osmium, phosphorus, sulfur, chlorine and nickel, deriving either from the fixative, the embedding medium or the grids, account for the other peaks

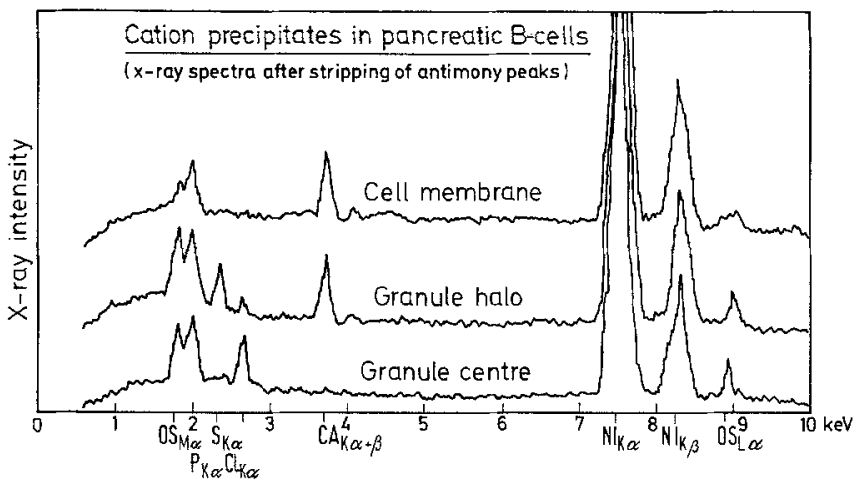

seen after acute AIS-induced hyperglycaemia. Heavy precipitates occurred within the granule halos and along the plasma membranes.

Interpretation of these findings in relation to their functional significance has to consider the following limitations. The free ionic calcium which is thought to be involved in secretory mechanisms $[6,7,8,35,36]$ probably represents only a minor portion of the total cellular calcium, while the majority appears to be pooled in storage organelles. The histochemical and ultracytochemical methods used cannot distinguish between free and stored calcium. The results obtained by these methods, therefore, only give information on the relative amounts of the total cellular calcium and on its subcellular distribution due to an artifactual or physiological binding to certain cell structures.

Despite these limitations the following conclusions can be drawn from the present data. Sulfonylureas act in a very similar way on the subcellular distribution of calcium within the B-cells as does acute AIS-induced hyperglycaemia. The changes in the subcellular distribution of calcium within the B-cells are probably due to molecular alterations of the plasma and granule membranes and the matrix closely associated with these structures, which result in an altered calcium permeability and intracellular deposition. Differences between the action of sulfonylureas and AIS-induced hyperglycaemia on cytochemical calcium handling of the $\mathrm{B}$-cells only become obvious in later stages of B-cell activation, when the amount of precipitable calcium in the B-cells is kept constant or is slightly increased after sulfonylurea treatment, whereas it is decreased in chronic AIS-induced hyperglycaemia. As it can be suggested from our data and from other studies $[27,29]$ that the halolocated calcium is discharged together with the granule content in emiocytosis, it is most likely that the augmented B-cell degranulation following AIS treatment mainly accounts for the strong depletion of the islets in precipitable calcium. The efflux of calcium overcomes its influx under those conditions. In the less degranulated B-cells of sulfonylurea treated animals, 
on the contrary, the calcium influx into the B-cells can obviously keep up with, or even slightly exceed, the total calcium efflux. Thus no depletion of precipitable calcium occurs. Concerning the critical importance of calcium for stimulus-secretion coupling in insulin release $[4,6,11,13,14,27,33]$ and the assumption that sulfonylureas do not penetrate B-cell membranes [16] our data support the hypothesis that sulfonylureas exert their insulinotropic effect by changing the calcium permeability of the B-cell membrane, which in turn results in accumulation as well as subcellular redistribution of calcium, and subsequently in insulin release.

From the present results no conclusions can be drawn as to how calcium may trigger the mechanisms leading to emiocytosis of the insulin granules. Lacy and Malaisse $[23,28]$ proposed the hypothesis that calcium ions activate the contractile microtubular apparatus of the B-cell, which is thought to be responsible for intracellular granule transport. Matthews and Dean $[5,6,32]$ who offered a further hypothesis assume that the calcium ions facilitate emiocytosis by neutralizing negative charges on the surface of secretory granules and thereby diminish a normal electrostatic barrier between the inner surface of the cell membrane and the granule surface. So far the present ultracytochemical findings do not directly confirm either hypothesis. However, it must be kept in mind that the amount of free ionic calcium, relevant for induction of secretory mechanisms, may be too small for exact ultracytochemical localization. It remains, therefore, an open question, whether the alterations in the EDPP distribution pattern of activated B-cells are of direct functional significance for insulin secretion, or only represent an indirect, concomitant effect of the activated secretory mechanisms on intracellular calcium binding and localization.

Acknowledgments. The authors wish to thank Mrs. Katrin Baack, Miss Monika Fischer, Mrs. Kirsten Schuckart and Miss Ute Zeiger for their skilful technical assistance. We are also indebted to Kontron Application Laboratories, München, for cooperation in carrying out the $\mathrm{X}$-ray microanalyses.

\section{References}

1. Bulgre, R. E.: Use of potassium pyroantimonate in the localization of Nations in the rat kidney tissue. J. Cell Biol. 40, 79-94 (1969)

2. Clark, M. A., Ackermann, G. A.: A histochemical evaluation of the pyroantimonate-osmium reaction. J. Histochem. Cytochem. 19, 727-737 (1971)
3. Clemente, F., Meldolesi, J.: Calcium and pancreatic secretion. Subcellular distribution of calcium and magnesium in the exocrine pancreas of the guinea pig. J. Cell Biol. 65, 88-102 (1975)

4. Curry, D. L., Bennett, L. L., Grodsky, G. M.: Requirement for calcium ion in insulin secretion by the perfused rat pancreas. Amer. J. Physiol. (Lond.) 214, 174-178 (1968)

5. Dean, P. M.: Surface electrostatic-charge measurements on islet and zymogen granules: Effect of calcium ions. Diabetologia 10, 427-430 (1974)

6. Dean, P. M., Matthews, E. K.: Electrical activity in pancreatic islet cells: Effect of ions. J. Physiol. (Lond.) 210, 265-275 (1970)

7. Douglas, W. W.: Stimulus-secretion coupling: The concept and clues from chromaffin and other cells. Brit. J. Pharmacol. 34, 451-474 (1968)

8. Douglas, W. W., Rubin, R. P.: The role of calcium in the secretory response of adrenal medulla to acetylcholine. $\mathrm{J}$. Physiol. (Lond.) 159, 40-57 (1961)

9. Garfield, R. E., Henderson, R. N., Daniel, E. E.: Evaluation of the pyroantimonate technique for localization of tissue sodium. Tissue and Cell 4, 575-589 (1972)

10. Gomba, S., Szabo, J., Soltesz, B. M.: Electronhistochemical observations on the localization of sodium ions in glomerular basement membrane. Acta histochem. (Jena) 42, 367-372 (1972)

11. Hales, C. N., Milner, R. D. G.: The role of sodium and potassium in insulin secretion from rabbit pancreas. J. Physiol. (Lond.) 194, 725-743 (1968)

12. Heinze, E., Fussgänger, R., Teller, W. M.: Influence of calcium on insulin secretion in newborns. Pediat. Res. 7, 100-102 (1973)

13. Hellman, B.: The significance of calcium for glucose stimulation of insulin release. Endocrinology 97, 392-398 (1975)

14. Hellman, B., Idahl, L.-A., Lernmark, A., Sehlin, J., Täljedal, J.-B.: The pancreatic $\beta$-cell recognition of insulin secretagogous. Effects of calcium and sodium on glucose metabolism and insulin release. Biochem. J. 138, 33-45 (1974)

15. Hellman, B., Sehlin, J., Täljedal, J.-B.: Calcium uptake by pancreatic $\beta$-cells as measured with the aid of ${ }^{45} \mathrm{Ca}$ and mannitol- ${ }^{3}$ H. Amer. J. Physiol. 221, 1795-1801 (1971)

16. Hellman, B., Sehlin, J., Täljedal, J.-B.: The pancreatic B-cell recognition of insulin secretagogous. IV. Uptake of sulfonylureas by islet tissue. Diabetologia 9, 210-216 (1973)

17. Herman, L., Sato. T., Hales, C. N.: The electron microscopic localization of cations to pancreatic islets of Langerhans and their possible role in insulin secretion. J. Ultrastruct. Res. 42, 298-311 (1973)

18. Kashiwa, H. K.: Calcium in cells of fresh bone stained with glyoxal-bis-(2-hydroxyanil). Stain Technol. 41, 49-55 (1966)

19. Kern, H. F., Kern, D.: Die Feinstruktur der Langerhansschen Inseln der Ratte nach Einwirkung von HB 419. ArzneimittelForsch. 19, 1452-1456 (1969)

20. Klöppel, G., Altenähr, E., Freytag, G.: Elektronenmikroskopische Untersuchungen zur experimentellen Insulitis nach Injektion von Anti-Insulin-Serum. Virchows Arch. Abt. A 354, 324-335 (1971)

21. Klöppel, G., Schäfer, H.-J.: Die Bedeutung des Calciumtransportes für die Funktion der B-Zelle des Inselsystems. Verh. dtsch. Ges. Path. 57, 471 (1973)

22. Komnick, H., Komnick, U.: Elektronenmikroskopische Untersuchungen zur funktionellen Morphologie des Ionentransportes in der Salzdrüse von Larus argentatus. Z. Zellforsch. 60, 163-203 (1963)

23. Lacy, P. E.: Beta-cell secretion: From the standpoint of a pathobiologist. Diabetes 19, 895-905 (1970)

24. Lacy, P. E.: Light microscopic and electron microscopic changes in vitro of sulfonylureas. In: Handbuch der experimen- 
tellen Pharmakologie, vol. 29 (ed. H. Maske), pp. 427-437. Berlin-Heidelberg-New York: Springer 1971

25. Lee, J. C., Grodsky, G. M., Bennett, L. L., Smith-Kyle, D. F., Craw, L.: Ultrastructure of B-cells during the dynamic response to glucose and tolbutamide in vitro. Diabetologia 6, 542-549 (1970)

26. Loubatières, A.: Physiological and pharmacological aspects of the pancreas in the mode of action of hypoglycemic sulfonamides. Acta diabet. lat. 6 (Suppl. 1), 216-255 (1969)

27. Malaisse, W. J.: Insulin secretion: Multifactorial regulation for a single process of release. Diabetologia 9, 167-173 (1973)

28. Malaisse, W. J., Malaisse-Lagae, F.: A possible role for calcium in the stimulus-secretion coupling of glucose-induced insulin secretion. Acta diabet. lat. 7 (Suppl. 1), 264-275 (1970)

29. Malaisse, W. J., Pipeleers, D. G., Mahy, M: The stimulussecretion coupling of glucose-induced insulin release. XII. Effects of diazoxide and gliclazide upon ${ }^{45}$ calcium efflux from perifused islets. Diabetologia 9, 1-5 (1973)

30. Malaisse, W. J., Mahy, M., Brisson, G. R., Malaisse-Lagae, F.: The stimulus-secretion coupling of glucose-induced insulin release. VIII. Combined effects of glucose and sulfonylureas. Europ. J. clin. Invest. 2, 85-90 (1972)

31. Malaisse-Lagae, F., Malaisse, W. J.: Stimulus secretion coupling of glucose-induced insulin release. III. Uptake of ${ }^{45} \mathrm{cal}-$ cium by isolated islets of Langerhans. Endocrinology 88, 72-80 (1971)

32. Matthews, E. K., Dean, P. M.: The biophysical effects of insulin-releasing agents on islet cells. Postgrad. Med. J. 3, (December Suppl.), 21-23 (1970)

33. Milner, R. D. G., Hales, C. N.: The role of calcium and magnesium in insulin secretion from rabbit pancreas studied in vitro. Diabetologia 3, 47-49 (1967)

34. Orci, L., Stauffacher, W., Renold, A. E., Beaven, D., Lambert, A., Rouiller, C.: Ultrastructural events associated with the action of tolbutamide and glibenclamide on pancreatic B-cells in vivo and in vitro. Acta diabet. lat. 6 (Suppl. 1), 271-374 (1969)

35. Rasmussen, H.: Cell communication, calcium ion, and cyclic adenosine monophosphate. Science 170, 404-412 (1970)
36. Rubin, R. P.: The role of calcium on the release of neurotransmitter substances and hormones. Pharmacol. Rev. 22, 389-428 (1970)

37. Schäfer, H.-J., Klöppel, G.: Demonstration of calcium in pancreatic islets. Light microscopical observations in activated and inactivated B-celis of Mice. Virchows Arch. Abt. A 362, 1-12 (1974)

38. Schäfer, H.-J., Klöppel, G.: The significance of calcium in insulin secretion. Ultrastructural studies on identification and localization of calcium in activated and inactivated B-cells of mice. Virchows Arch. Abt. A 362, 231-245 (1974)

39. Spicer, S. S., Swanson, A. A.: Elemental analysis of precipitates formed in nuclei by antimonate-osmium tetroxide fixation. $\mathbf{J}$. Histochem. Cytochem. 20, 518-526 (1972)

40. Stoeckel, M. E., Hindelang-Gertner, C., Dellmann, H.-D., Porte, A., Stutinsky, F.: Subcellular localization of calcium in the mouse hypophysis. I. Calcium distribution in the adeno- and neurohypophysis under normal conditions. Cell Tiss. Res. 157, 307-322 (1975)

41. Torack, R. M., Lavalle, M.: Specificity of the pyroantimonate technique to demonstrate sodium. J. Histochem. Cytochem. 18, 635-643 (1970)

42. Williamson, J. R., Lacy, P. E., Grisham, J. W.: Ultrastructural changes in islets of the rat produced by tolbutamide. Diabetes 10, 460-469 (1961)

43. Witzel, D. A., Littledike, E. T.: Suppression of insulin secretion during induced hypoglycemia. Endocrinology 93, 761-766 (1973)

Received: November 28, 1975, and in revised form: February 23, 1976

Dr. med. G. Klöppel

Pathologisches Institut

der Univ.

Martinistraße 52

2000 Hamburg 20

Federal Republic of Germany 